\title{
Framing the Challenge of Climate Change in Nature and Science Editorials
}

\author{
Mike Hulme $^{1 *}$, Noam Obermeister ${ }^{2}$, Samuel Randalls ${ }^{3}$, Maud Borie ${ }^{4}$ \\ ${ }^{1}$ Department of Geography, Downing Place, University of Cambridge, \\ Cambridge CB2 3EN [* Corresponding author] \\ 2 Independent Researcher, London, UK \\ 3 Department of Geography, University College London, Gower Street, London WC1E 6BT \\ ${ }^{4}$ Department of Geography, King's College London, Strand, London WC2R 2LS
}

\begin{abstract}
Through their editorialising practices, leading international science journals such as Nature and Science interpret the changing roles of science in society and exert considerable influence on scientific priorities and practices. Here we examine nearly 500 editorials published in these two journals between 1966 and 2016 which deal with climate change, thereby constructing a lens through which to view the changing engagement of science and scientists with the issue. A systematic longitudinal frame analysis reveals broad similarities between Nature and Science in the waxing and waning of editorialising attention given to the topic. But although both journals have diversified how they frame the challenges of climate change, they have done so in different ways. We attribute these differences to three influences: the different political and epistemic cultures into which they publish; their different institutional histories; and their different editors and editorial authorship practices.
\end{abstract}


There are many ways of mapping and analysing discourses of climate change over time. Earlier studies have followed print and broadcast media ${ }^{1,2}$, publishing trends in scientific journals ${ }^{3}$, political speeches ${ }^{4}$ and international negotiations $s^{5}$, evolving linguistic ${ }^{6}$ and visual vocabularies ${ }^{7}$, public perceptions of climate risk $^{8}$, social dramas ${ }^{9}$ and careers of individual scientists ${ }^{10,11}$. However, the editorial content of leading science journals may also reveal the changing nature of the challenge climate change presents to science and society alike.

Given their status as prestigious multi-disciplinary scientific journals ${ }^{12}$, Nature and Science are routinely read not just by scientists, but also by academics more widely and by science-policy analysts, science journalists and policy advisors. For example, the science pages of influential newspapers such as Le Monde, The Times (of London) and The New York Times frequently refer to new research published in these two journals. Nature also lends its support to a media centre to brief journalists and civil servants about breaking science stories $^{13}$ and the professional body which publishes Science (the American Association for the Advancement of Science; AAAS) recently launched an equivalent service (SciLine) in the United States ${ }^{14}$. Nature and Science therefore act as key sites for the production, interpretation and circulation of knowledge in scientific, academic and influential policy and media networks. Although processes for validating scientific knowledge continue to change, peer-review remains one of the chief means through which knowledge is assessed, validated and rendered authoritative ${ }^{15,16}$. Peer-reviewed journals therefore actively contribute to the creation of what is accepted as reliable and authoritative knowledge ${ }^{17}$. Nature and Science should be thought of alongside laboratories, observatories, field sites, conferences and assessment processes as influential spaces where knowledge is not merely communicated, but actively constructed and authorised ${ }^{18,19,20}$. In this sense, leading science journals become essential nodes for communication not just between scientists, but also between science and other social worlds.

One central feature of weekly journals such as Nature and Science is the editorial. An editorial is a short article that expresses either the editor's or an invited author's opinion on a topical subject of particular interest to the journal's readership. Editorials have been present in both journals since their founding (Nature in 1869; Science in 1880) and became regular top-line weekly items in Nature from the 1920s and in Science from the early 1950s. Baldwin's history of the journal Nature notes the importance of the Nature editorial and 
observes how "editorial styles might affect the reception and reputation of the journal"21. Editorials are distinct from other science journal content in being opinionated commentaries and they are understood to be such by their readers. They are typically written in an informal or provocative manner, interpreting current scientific events and controversies, setting out agendas, engaging in advocacy and passing judgement on matters of concern and political dispute. Editorials can therefore reveal some of the value-laden dimensions of science, sometimes quite explicitly, and also, perhaps less visibly, the influence of political and epistemic cultures on scientific practice ${ }^{22}$. In widely-read journals like Nature and Science, editors or invited editorial authors have a platform to signal to elite audiences-both inside and outside science--what they believe should be the scientific and political priorities of the scientific enterprise. Editorials in Nature and Science have individual DOIs and are cited as sources in academic articles ${ }^{23}$ (see Supplementary Note $1 \&$ Table 1 ).

Editorials therefore exert influence; in other words, they are 'performative ${ }^{24,25}$. The backlash against Nature's editorial in September 2017 on commemorative statues of deceased scientists illustrates the point. Nature's editor, Philip Campbell, was forced to apologise for failing "to rise to our standards of argument and editorial treatment" 26 and undertook to review the journal's internal editorial practices. This potential to influence professional scientists and wider public discourse makes the content of editorials in high profile journals especially interesting to study ${ }^{27}$. There have been a few studies analysing editorials in medical journals. For example, Hoey and Todkill (Ref. 28) commented on the politics and ethics of editorials in the Canadian Medical Association Journal, while Smart et al. (Ref. 29) analysed how editorials in biomedical science journals sought to standardise classifications of race and ethnicity. With specific regard to Nature and Science editorials, only Waaijer and colleagues have conducted systematic study. In a bibliometric analysis of Nature's and Science's editorials during the decade 2000-2009, Waaijer et al. ${ }^{23}$ hint at both similarities and differences in editorial content between these two journals. A later study analysed these same journals' editorials with respect to their positioning on the challenges of pursuing careers in science ${ }^{30}$.

In the present study we systematically analyse how Nature and Science have editorialised about climate change over the last 50 years. In particular, we ask two questions. What attention and framing patterns with regards to climate change can be 
detected in editorial content and can these patterns be related to wider political or scientific events? In what ways, if any, do Nature and Science editorialise differently about climate change and how might these differences be explained? Answers to these questions are important since they will shed light on how science's editors represent climate change to their audiences and the extent to which these two leading science journals speak with one voice on this important public and global issue. This study breaks new ground both conceptually - through a systematic longitudinal interpretative analysis of science journal editorials - and topically through its focus on the content of climate change editorials.

\section{About Nature and Science}

Although Nature and Science are both high-impact science journals that editorialise on a weekly basis, the origins, institutional history and editorial practices of these two journals are very different (Table 1). Of particular note is that Nature is an independent journal published by the Nature Publishing Group, since 2015 the academic publishing division of the international conglomerate Springer-Nature. In contrast, Science is the weekly flagship journal of the non-profit professional body of American scientists, the AAAS. This explains the larger number of subscribers for Science than for Nature (c.130,000 cf. c.55,000, even though readership of Nature is likely larger than that of Science (Table 1). Headquartered in London, Nature Publishing Group has several offices worldwide, whereas Science is based in Washington DC, with just one subsidiary office in Cambridge, UK.

Table 1: Main attributes of the journals Science and Nature. Sources: Ref 21 (pp.175,188, 224); Ref 31.

\begin{tabular}{|l|l|l|}
\hline & \multicolumn{1}{|c|}{ Nature } & \multicolumn{1}{c|}{ Science } \\
\hline $\begin{array}{l}\text { Creation of the } \\
\text { journal }\end{array}$ & $\begin{array}{l}\text { 1869. Independent weekly journal, now } \\
\text { published by Springer-Nature. }\end{array}$ & $\begin{array}{l}\text { 1880. Weekly journal of the American } \\
\text { Association for the Advancement of } \\
\text { Science. }\end{array}$ \\
\hline $\begin{array}{l}\text { Location of } \\
\text { headquarters }\end{array}$ & $\begin{array}{l}\text { Multi-sited. Nature Research is a global } \\
\text { company with offices worldwide, but } \\
\text { management and principal publishing } \\
\text { offices are in London, New York and Tokyo. }\end{array}$ & $\begin{array}{l}\text { Main HQ in Washington DC, with a } \\
\text { European office in Cambridge. }\end{array}$ \\
\hline
\end{tabular}




\begin{tabular}{|l|l|l|}
\hline $\begin{array}{l}2017 \\
\text { subscriptions }\end{array}$ & $\begin{array}{l}\text { Paid = 30,628 } \\
\text { Total = 53,270 (47\% in USA) }\end{array}$ & $\begin{array}{l}\text { Paid = 114,126 } \\
\text { Total = 129,564 (84\% in USA) }\end{array}$ \\
\hline $\begin{array}{l}\text { Journal Impact } \\
\text { Factors }\end{array}$ & $\begin{array}{l}2011 \text { CiteScore =14.0 } \\
2016 \text { CiteScore =13.3 (JIF=40.1) }\end{array}$ & $\begin{array}{l}\text { 2011 CiteScore = 12.0 } \\
\text { 2016 CiteScore = 14.4 (JIF=37.2) }\end{array}$ \\
\hline $\begin{array}{l}\text { Editors in our } \\
\text { study period }\end{array}$ & $\begin{array}{l}\text { John Maddox 1966-1973 } \\
\text { David Davies 1973-1980 } \\
\text { John Maddox 1980-1995 } \\
\text { Philip Campbell 1995-present }\end{array}$ & $\begin{array}{l}\text { Phil Abelson 1962-1984 } \\
\text { Daniel Koshland 1984-1995 } \\
\text { Floyd Bloom 1995-2000 } \\
\text { Donald Kennedy 2000-2008 } \\
\text { Bruce Alberts 2008-2013 } \\
\text { Marcia McNutt 2013-2016 } \\
\text { Jeremy Berg 2016-present }\end{array}$ \\
\hline $\begin{array}{l}\text { Published } \\
\text { editorials in our } \\
\text { period (1966- } \\
\text { 2016) }\end{array}$ & c.6000 & c.2650 \\
\hline $\begin{array}{l}\text { Editorials in our } \\
\text { final corpus }\end{array}$ & N=333 (c.5.6\%) & Attributed; frequently invited authors \\
\hline $\begin{array}{l}\text { Editorial } \\
\text { authorship }\end{array}$ & Authored by the editor & N=160 (c.6\%) \\
\hline
\end{tabular}

During the period of our study Nature had just three editors (Maddox served two terms) and Science a total of seven (Table 1). John Maddox and Phil Abelson were the respective chief editors for the two journals during the earlier decades of our period and both editors were very influential in 'modernising' their respective journals ${ }^{32,21}$. During the 1970s and 1980s they professionalised editing processes and sought to position their journals within the burgeoning international and increasingly mobile community of scientists. Nature's editorials have always been published anonymously, although usually written by the journal's chief editor ${ }^{21}$, in contrast to Science which has always operated a practice of named authors, frequently inviting external guests to editorialise (see Supplementary Table 2). For example, President Clinton (June 1997) wrote about the promise of science in the twenty-first century and President Obama (January 2017) about clean energy. During the period of our study Science has published just a single editorial each week, whereas Nature has varied between one and three editorials weekly, with three latterly becoming the norm.

\section{Editorial challenge and attribute frames}


We extracted a relevant corpus of climate change editorials for the period 1966-2016 using search terms 'climate', 'greenhouse', 'carbon', 'warming', 'weather', 'atmosphere' and 'pollution' as an initial filter and subjected it to frame analysis (see Methods). The final corpus consisted of 493 editorials, 333 for Nature and 160 for Science, representing for both journals between $5 \%$ and $6 \%$ of all editorials published during this period. Our frame-set distinguished between eight different 'challenges' and three different 'attributes' (see Table 2). Each of the 493 editorials was allocated a single primary frame (i.e., the dominant 'challenge' of climate change) and, if appropriate, any number of additional 'other' challenges selected from the frame-set. 'Attributes' for each editorial were coded as a simple binary-presence or absence--as appropriate. Inter-coder reliability improved through two pilot exercises and collaborative coding (see Methods).

Table 2: Final frame-set used in coding the editorials.

\begin{tabular}{|c|c|}
\hline & CHALLENGES \\
\hline $\begin{array}{l}\text { ECON = Economic/financial } \\
\text { challenge }\end{array}$ & $\begin{array}{l}\text { Climate change is an externality of economic growth and/or certain modes of } \\
\text { production/consumption and/or requires improved quantification of costs/benefits } \\
\text { of impacts and/or policies and/or can/should be tackled through economic \& } \\
\text { financial instruments }\end{array}$ \\
\hline DEV = Developmental challenge & $\begin{array}{l}\text { Climate change is a by-product of pathways and patterns of socio-economic } \\
\text { development and/or unequal development inhibits adequate mitigation, resilience } \\
\text { and adaptation and/or causes uneven distribution of harms to human health, well- } \\
\text { being and perceived human security }\end{array}$ \\
\hline $\begin{array}{l}\text { SEC = National/international } \\
\text { security challenge }\end{array}$ & $\begin{array}{l}\text { Climate change is a geopolitical security risk by introducing new dangers into inter- } \\
\text { and intra-state relations and/or is a threat-multiplier requiring new forms of } \\
\text { international or state-level security responses }\end{array}$ \\
\hline ETH = Ethical/Moral challenge & $\begin{array}{l}\text { Climate change raises important questions of procedural and/or distributive justice } \\
\text { (e.g. burden-sharing) and/or people have an ethical responsibility/moral duty } \\
\text { towards future humanity and/or nature and/or the 'poor'/the most vulnerable } \\
\text { and/or God/deities, to mitigate climate change }\end{array}$ \\
\hline $\begin{array}{l}\text { TECH = Technological/ } \\
\text { Energy challenge }\end{array}$ & $\begin{array}{l}\text { Fossil-fuel based energy technologies are the root cause of climate change and/or } \\
\text { technological innovation and energy transitions that aim at } \\
\text { reducing/capturing/sequestering GHG emissions and/or solar engineering } \\
\text { technologies are essential to tackle climate change. }\end{array}$ \\
\hline $\begin{array}{l}\text { GOV = Institutional/ } \\
\text { governance challenge }\end{array}$ & $\begin{array}{l}\text { Structural and institutional inertia/problems are a root cause of climate change } \\
\text { and/or tackling climate change requires new/improved governance institutions }\end{array}$ \\
\hline
\end{tabular}




\begin{tabular}{|l|l|}
\hline & $\begin{array}{l}\text { and/or regulatory management of adaptation/mitigation policies is inadequate } \\
\text { [not to be used if this governance challenge is covered by a more specific frame] }\end{array}$ \\
\hline $\mathbf{S C l}=$ Scientific challenge & $\begin{array}{l}\text { Scientific understanding of climate change is incomplete/inadequate (i.e., due to } \\
\text { complexity/uncertainty) and/or investing in science is necessary for adequate } \\
\text { mitigation/adaptation responses }\end{array}$ \\
\hline COM = Communication challenge & $\begin{array}{l}\text { Climate science and climate risks is/are poorly communicated to public audiences } \\
\text { and/or media representations of climate change are problematic/biased and/or } \\
\text { deliberate misinformation/manufactured scepticism confuses political/public } \\
\text { opinion }\end{array}$ \\
\hline $\begin{array}{l}\text { Global/ } \\
\text { Collective scale }\end{array}$ & $\begin{array}{l}\text { The editorial draws attention to the global/collective/cooperative/supra-national } \\
\text { scales of the stated response(s) to the designated challenge(s) }\end{array}$ \\
\hline Urgency & $\begin{array}{l}\text { The editorial draws attention to the temporal/political urgency with which the } \\
\text { designated challenge(s) should be addressed }\end{array}$ \\
\hline Policy & $\begin{array}{l}\text { The editorial draws attention to specific policy instruments and/or measures which } \\
\text { are being implemented/or should be implemented in order to respond to the } \\
\text { designated challenge(s) }\end{array}$ \\
\hline
\end{tabular}

Both journals show broadly similar frequency patterns in their climate change editorialising (Figure 1). During the first two decades very few editorials addressed climate change as an issue and, of those that did, several were written to resist or downplay environmentalist claims. For example in 1970, Fred Singer-as Chair of the Committee on Environmental Quality at the AGU-wrote a guest editorial for Science about the danger of 'exaggerated claims'33, whilst the following year Nature's editor, John Maddox, wrote an editorial about 'the great greenhouse scare ${ }^{34}$. Until the mid-1980s many of the issues of the day-atmospheric pollution, energy security, poverty, development, internationalisation of science--were editorialised in both journals with little, if any, consideration of climate or climate change. However, the late 1980s saw the well-established emergence of climate change as a salient public policy issue in the USA and western Europe ${ }^{35}$ and this is clearly reflected in these journals' editorialising. 1988 was the first year in which more than two 'climate change editorials' (according to our definition) were published in both journals. The later, more global, prominence given to climate change in public arenas from the mid2000 s through to $2010^{1}$ is also clearly reflected in editorial attention. Indeed, for every year since 2004 Nature has published at least 10 'climate change editorials'. Science's 
editorialising about climate change peaked in 2007 ( $n=14$; more than $25 \%$ of all editorials that year), Nature's in 2009 ( $n=31$; around 20\% of all editorials) and while the decline in editorial attention after COP15 at Copenhagen is evident in both journals, the decline was more pronounced in Science (notably in 2011 and 2012).
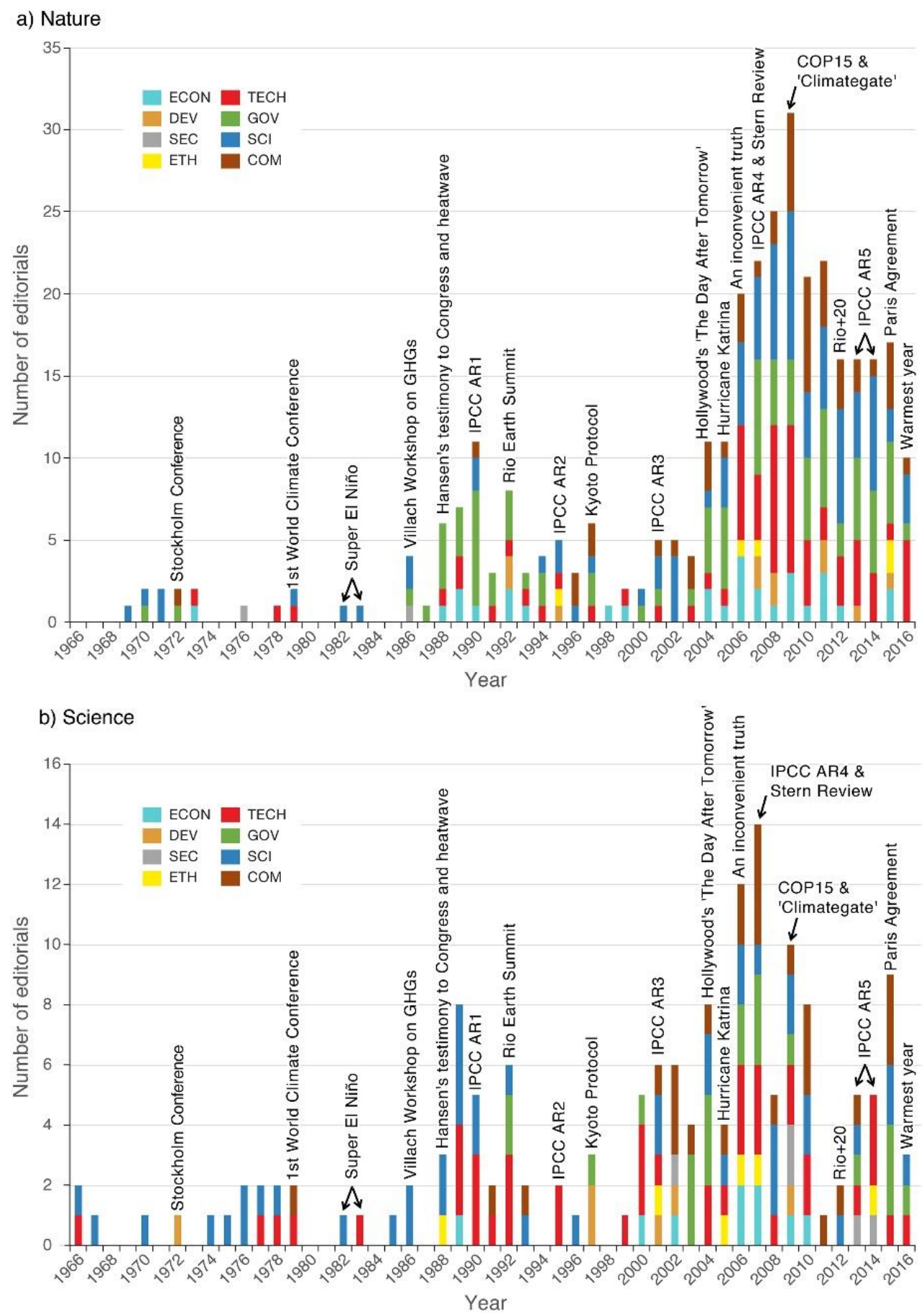
Figure 1. Primary challenge frames. The frequency of primary challenge frames by year in $A)$ Nature's climate change editorials $(n=333)$ and $B)$ Science's climate change editorials $(n=$ 160). Some key scientific, political, cultural and meteorological events (cf. Ref 1) relating to climate change are overlain on each graph. ECON = economic/financial, DEV = developmental, $S E C=$ national/international security, $E T H=$ ethical $/ \mathrm{moral}, \mathrm{TECH}=$ technological, $\mathrm{GOV}=$ institutional/governance, $\mathrm{SCl}=$ scientific, $\mathrm{COM}=$ communication (see Table 2 for full frame code definitions).

These peaks and troughs, evidenced similarly in both journals, closely track patterns of attention to climate change found in popular media ${ }^{1}$. These patterns are partly driven by key scientific, political, cultural and meteorological events concerning climate change (Figure 1), but also reflect the competition dynamics between different 'social problems' seeking access to scarce media resources available in public arenas ${ }^{36}$. As leading scientific journals, perhaps of greatest interest for Nature and Science were the five major assessment reports of the Intergovernmental Panel on Climate Change (IPCC) published in 1990, 1996, 2001, 2007 and 2013/14.

\section{Editorial framings by era}

To better reveal the changing patterns in editorial framings we periodised the data according to these publication dates, thus generating six eras: the pre-IPCC era (pre-1988) and then five 'IPCC eras', each of which commences two years prior to publication and ends two (or three) years after (Figure 2). There has been a diversification over time in how climate change has been framed. In the earlier three eras, both journals primarily framed climate change as a scientific, energy/technology or institutional/governance challenge; $78 \%$ of all editorials prior to 1999 had their primary frame as one of these three categories. In the later three eras-'AR3', 'AR4' and 'AR5' - this fell to 67\%.

This frame diversification was much more pronounced for Science (85\% down to $58 \%$ ) than for Nature (73\% to $71 \%$ ). Especially noteworthy was the increase in framings of climate change as a communication challenge (e.g Ref ${ }^{37}$ ), up from $7 \%$ of all editorials prior to the 'AR3-era' to $18 \%$ since then. This move is again more noticeable for Science (6\% to $22 \%$ ) than for Nature ( $8 \%$ to $16 \%$ ). In the 'AR5-era', the communication challenge as a 
primary frame is almost on a par with those of science, energy/technology and institutions/governance (Figure 3). Two other points are noteworthy. Climate change as an economic/financial challenge (e.g. Ref ${ }^{38}$ ) was most prevalent for both journals in the 'AR4era' (2005-2010), coinciding with the publication of the Stern Review on the economics of climate change in $2007^{39}$. And the identification of climate change as an ethical/moral challenge (e.g. Ref ${ }^{40}$ ) has been notable only since 2005 . Since then, $6.5 \%$ of all editorials have adopted this challenge as their primary frame and a further $5.5 \%$ as an additional frame (Figure 2).

a) Nature, Primary frames

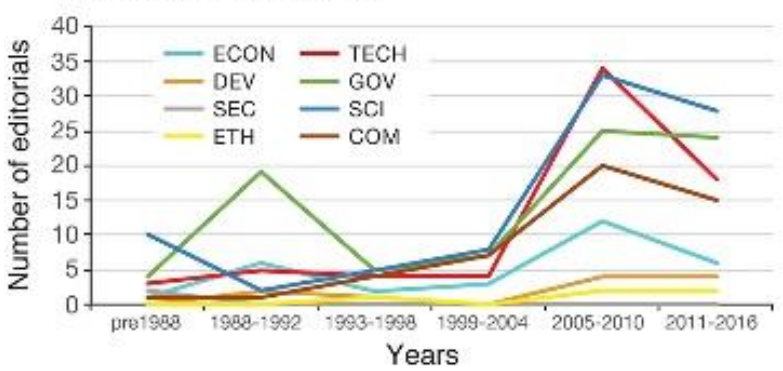

c) Nature, All frames

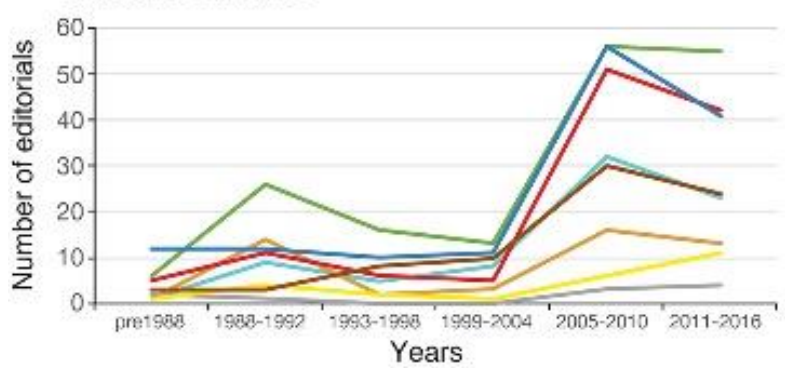

b) Science, Primary frames

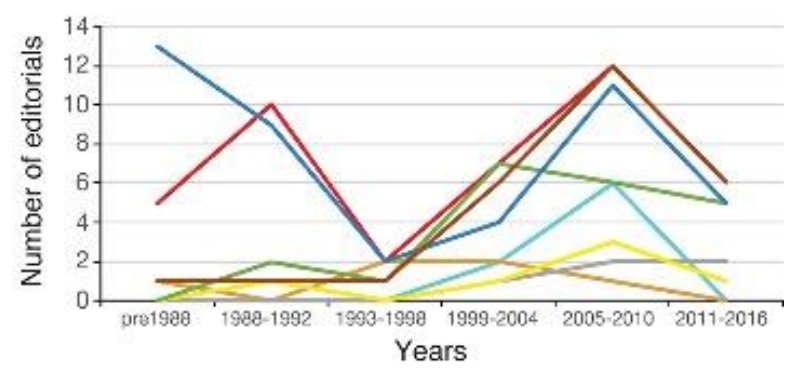

d) Science, All frames

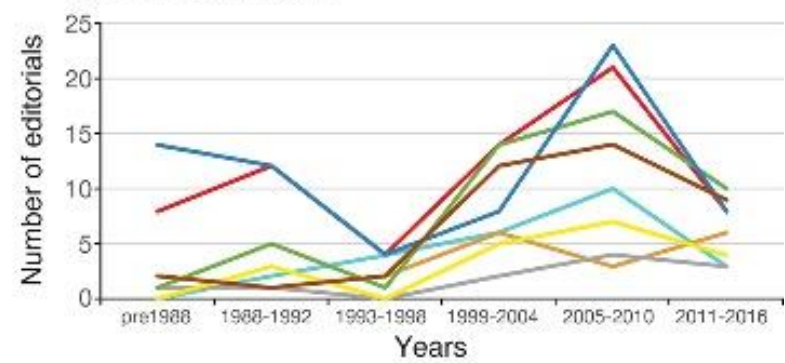

Figure 2: Challenge frames by IPCC era. The absolute frequencies of primary frames (A) and $(B)$ and all frames $(C)$ and $(D)$ in Nature $(A)$ and $(C)$ and in Science $(B)$ and $(D)$ editorials for each IPCC era. $E C O N=$ economic/financial, $D E V=$ developmental, $S E C=$ national/international security, ETH = ethical/moral, TECH = technological, GOV = institutional/governance, $\mathrm{SCl}=$ scientific, $\mathrm{COM}=$ communication (see Table 2 for full frame code definitions).

Despite these broad similarities, there are some important differences in how these two journals editorialise about climate change. This is evident, for example, from the first attention peak during the 'AR1-era', 1988-1992. For Nature's editorials in this period, 
climate change was primarily an institutional/governance challenge, whereas for Science it was largely either a technology/energy (42\% of all editorials framed thus) or a scientific challenge (38\%). In contrast to 54\% of Nature's editorials during 1988-1992 framing climate change as an institutional/governance challenge, only $8 \%$ of Science's editorials did so. Nature only began to give significant emphasis to the technology/energy challenges of climate change from the 'AR4-era' onwards, while Science only began seriously to emphasise the institutional/governance challenge from the 'AR3-era' onwards (Figure 2). Over the whole period of the study, Nature emphasises the institutional/governance challenges of climate change much more than does Science: $51 \%$ of its editorials have this as at least one of its multiple frames, compared to only $30 \%$ for Science.

There are also significant differences in the attributes attached to the two journals' editorials. Although both journals frequently frame climate change as a 'global' challenge, Science has increasingly emphasised this attribute over time, more than doubling from 'AR1era' to 'AR5-era' its percentage of editorials so framed (Figure 3). Science has also framed climate change more frequently as 'urgent', noticeably during the most recent 'AR5-era'. Conversely, Nature has been much more willing to comment on policy instruments and measures ( $27 \%$ of editorials with the 'policy' attribute) than has Science (17\%). In summary, while both journals frequently, and in broadly equal proportion ( $26 \%$ and $27 \%$ ), primarily frame climate change as a scientific challenge (e.g. Ref ${ }^{41}$ ), as might be expected, Nature pays more attention to the institutional/governance aspects of the challenge and is more engaged in discussing specific policy instruments, including economic/financial challenges. In contrast, Science emphasises the technology/energy challenges of climate change and, especially latterly, the communication challenge. 
a) Nature

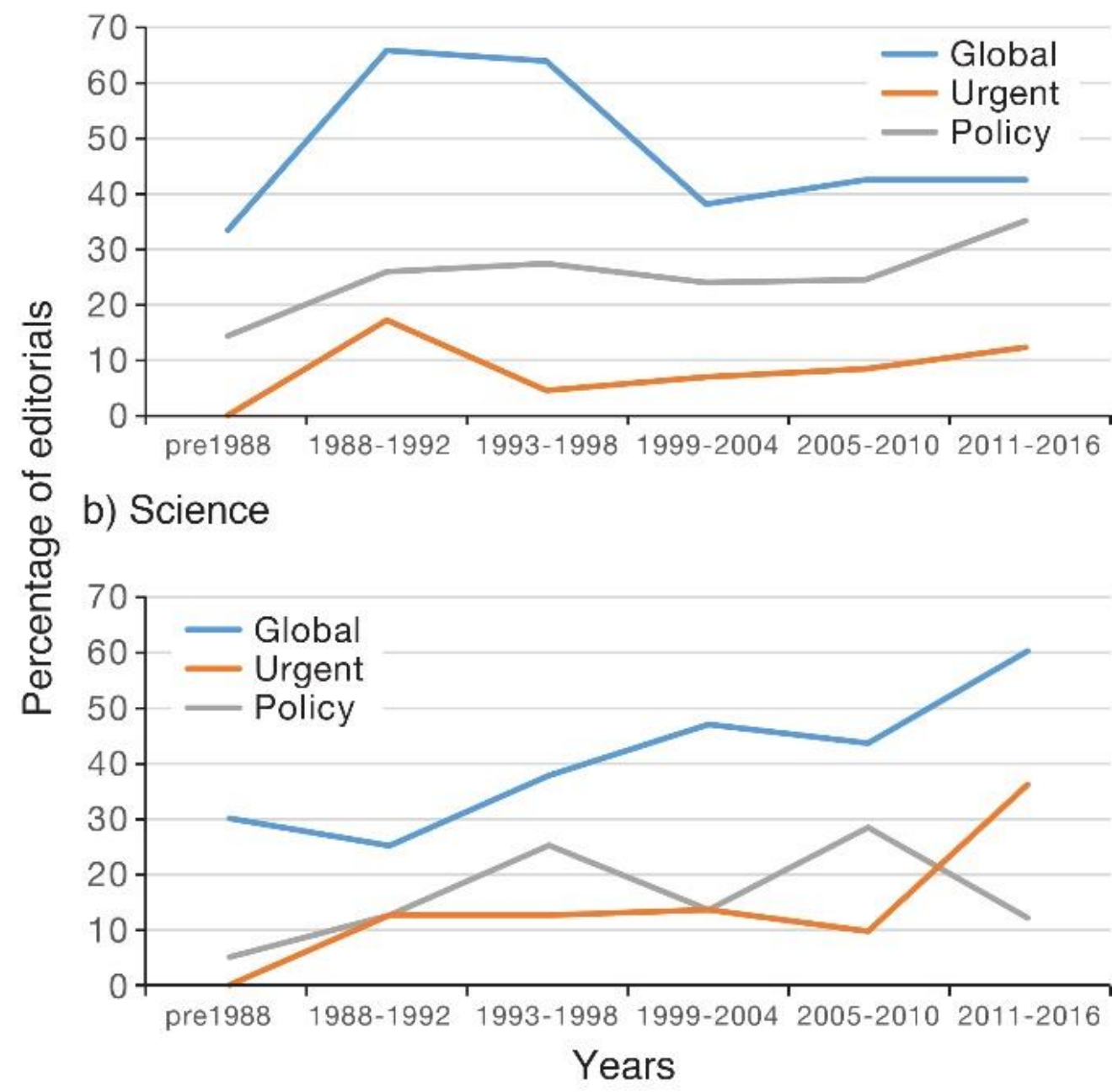

Figure 3: Attribute frames by IPCC era. The percentage of editorials in each 'IPCC-era' displaying specified 'attributes' for: A) Nature (top); and B) Science (bottom). For 'attribute'definitions refer to Table 2.

\section{Discussion}

Although both journals have greatly increased their editorial attention to climate change in recent decades, this attention has been episodic--notably peaking around 1990, in the years leading up to 2009 and then again in 2015. These peaks are partly related to external events in the worlds of science (e.g. IPCC reports), politics (e.g. the Copenhagen Summit, the Paris Agreement), public culture (e.g. films such as An Inconvenient Truth; controversies such as Climategate) and meteorological events (e.g. the American drought of 1988). These attention patterns broadly follow those found elsewhere in popular media outlets, especially newspapers ${ }^{1,35}$. This suggests that Nature's and Science's editorial decision- 
making partly reflects the mainstream media's framing of social problems. The editorials also reveal how over time climate change has become a sufficiently familiar 'matter of concern' that it increasingly is used to illustrate wider issues which occupy editorial attention; for example the relationship between science and development, the challenges of science communication, the internal organisation of science, science funding, and so on. This partly explains the diversification of frames noted above, especially notable in the case of Science (but here more diverse authorship is important; see below).

Yet our results also reveal some significant differences in framings between the two journals. Nature has consistently emphasised the international institutional/governance challenges of climate change to a much greater extent than has Science and has remained more willing to comment directly on policy instruments and measures (e.g. Ref. ${ }^{42}$ ). In contrast, for a long time Science framed climate change predominantly in terms of either scientific or energy/technology challenges and yet in recent years has widened its framings considerably. It has retained a more sustained emphasis on the public communication challenges of climate change than has Nature, increasingly framing climate change as global and urgent (e.g. Ref. ${ }^{43,44}$ ), whilst at the same time retreating in recent years from commenting directly on specific policy instruments and measures.

We suggest that the different political cultures in which these journals operate, and their different institutional histories, may partly explain these differences. Science's editorialising is influenced by the polarised cultural politics of climate change found in the United States and by certain conceptions of the role and legitimisation of science in society. These 'local influences' on Science are reinforced by the journal's role as the 'house magazine' for the professional association of American scientists, which is the primary audience for its editorials. In contrast, Nature has no comparable institutional audience and yet it too operates within a distinctive political and epistemic culture. Its editorialising about climate change seems to reflect a more cosmopolitan perspective on science in general ${ }^{21}$ and a more internationalist perspective on climate change in particular. This latter position is shaped by the distinct British/European self-perception of its 'climate change leadership' 45 extending back to the late 1980s. Although both journals report developments in international science and publish new science from all around the world, in this sense seemingly offering on climate change a 'view from nowhere'46, neither journals' 
editorialising escapes the pull of their respective operating cultures. The differences in climate change framings found in these scientific journals have some similarities with those found in comparative trans-Atlantic studies of newspaper framings of climate change. US media frame climate change more as a scientific puzzle to be understood, compared to UK media which engage more directly with solutions and policies ${ }^{47}$.

Yet differences in political cultures is only part of the explanation for differences between Nature and Science. Also significant are the personalities, priorities and practices of the specific editors who commission or author individual editorials and the differences in the author profiles between the two journals. Nature's editorials are always unsigned, leaving it ambiguous as to the specific authorial voices being expressed in each case. We know that Nature's editor is "ultimately accountable for Nature's content" 26 and yet the cloak of anonymity is rarely if ever removed. On the other hand, Nature editor John Maddox's provocative stance with regards to environmentalism in the $1970 \mathrm{~s}^{21}$ undoubtedly influenced some of this journal's early editorial content on climate change ${ }^{32}$ and Campbell's tenure as editor since 1995 means that he has commissioned (if not written) 80\% of Nature's climate change editorials. Campbell, an astrophysicist who first started working for Nature in 1979, has therefore exerted significant personal influence in developing Nature's editorial stance on climate change over the last 25 years.

Science's practice of attributed editorials is in sharp contrast to Nature and means that it is possible to analyse authorship patterns and profiles (see Supplementary Information Note 2 ). Whilst around $57 \%$ of editorials have been authored directly by editors or other AAAS staff, this still leaves a significant diversity of voices speaking for science through the editorials of Science. Only $16 \%$ of these authors had affiliations outside the USA. The influence exerted by specific editors at Science can also be traced, whether it be Abelson's focus on 'energy/technology' and 'science' challenges, the significant attention Kennedy gave since 2000 to climate change's 'communication' and 'institutional/governance' challenges, or McNutt's very deliberate foregrounding between 2013 and 2016 of female authorship (see Supplementary Information Table 2). Inviting guest editorials is a practice that has become more common at Science, as too has coauthorship, and likely contributes to explanations of why its editorial framings of climate change have diversified more than have Nature's (Figure 2). That Science's editorials are 
always attributed is also significant with regards to their subsequent visibility. Although both journals' editorials have similar salience in terms of altmetric scores, Science's editorials are much more likely to be formally cited in academic literature (Supplementary Note 1), probably because attribution allows them to be traced more easily and unambiguously.

There are a number of limitations to this study. As with all framing analysis, unambiguous and fully objective frames are not attainable, although our careful iterative construction of the frame-set and our separation of 'challenges' from 'attributes', and of 'primary' from 'other' frames, affords a robust interpretative framework for analysis (see Methods). We have not been able to study at first-hand, either through ethnography or interviews, the editorial decision-making processes that operate within these two journals. Such approaches might offer further insights into the boundary-ordering work ${ }^{48}$ performed by these editorials. And there have also been significant changes during the study period in scientific publishing culture and audience reach and attention which we have not analysed.

Our study offers a first sight of how editorialising attention and framing works in the case of climate change for Nature and Science. We suggest that scientific journal editorials could be studied more closely for revealing some of the ways in which science and society shape each other. They reveal some of the tensions between global kinds of knowledge brought forward by science and the local meanings of such universal knowledge when inserted into specific political cultures ${ }^{49}$. Editorials in science journals make important interventions across the boundaries of science, society, ethics and politics, whereby science stakes both its claim to epistemic authority and its relevance for policy-making. Yet these claims never entirely escape the centripetal pull exerted by the journals' institutional histories and political geographies. As geographers of science have frequently shown, 'place' matters in the making and interpreting of scientific knowledge ${ }^{15,50,51}$. But this study has also shown that the profile and priorities of individual editors matters for the way in which, through their editorialising, these two leading science journals give shape and meaning to a challenge like climate change. Science never can nor ever does speak for itself, not least unto the worlds of climate politics and public policy. Understanding science's editorial filters, as exemplified here in the case of Nature and Science, also shows that science's editors never speak with one voice. 
Correspondence and request for materials should be sent to M Hulme <mh903@cam.ac.uk>

\section{Author Contributions}

M.H. initiated and designed the study and led on writing; N.O. and M.H. extracted the corpus; M.H., N.O., S.R. and M.B. all contributed to coding, analysis, interpretation and improvements to the text; N.O. and S.R. contributed statistical analysis and graphics; M.B. conducted a literature review, analysed citation and altmetric scores, and extracted author details of Science editorials.

\section{Competing Interests}

The authors declare no competing financial interests.

\section{References}

1. Boykoff,M.T. Who Speaks for the Climate? Making Sense of Media Reporting on Climate Change (Cambridge: Cambridge University Press, 2011).

2. Hoffman,A.J. Talking past each other? Cultural framing of skeptical and convinced logics in the climate change debate Organisation and Environment 24(1), 3-33 (2011).

3. Henderson-Sellers,A. Climatic change: communication changes over this journal's first 'century' Climatic Change 100, 215-227 (2010).

4. Climate Outreach Starting a New Conversation on Climate Change with the European Centre-Right (Climate Outreach: Oxford, 2015, accessed 20 December 2017). https://climateoutreach.org/resources/starting-a-new-european-conversation-onclimate-change-with-the-centre-right/

5. Aykut,S.C., Foyer,J., Morena,E. (eds.) Globalizing the Climate: The Global Climate Debate after COP21 (Abingdon: Routledge, 2017).

6. Nerlich,B. \& Koteyko,N. Compounds, creativity and complexity in climate change communication: the case of 'carbon indulgences' Global Environmental Change 19(3), 345-353 (2009). 
7. O'Neill,S.J. \& Smith,N. Climate change and visual imagery WIREs Climate Change 5(1), 73-87 (2014).

8. Capstick,S., Whitmarsh,L., Poortinga,W., Pidgeon,N., \& Upham,P. International trends in public perceptions of climate change over the past quarter century WIREs: Climate Change 6(1), 35-61 (2015).

9. Smith,P. \& Howe,N. Climate Change as Social Drama: Global Warming in the Public Sphere (New York, Cambridge University Press, 2015).

10. Schneider,S.H. Science as a Contact Sport: Inside the Battle to Save Earth's Climate (Washington, DC: National Geographic Society, 2009).

11. Hulme,M. Exploring climate change through science and in society: an anthology of Mike Hulme's essays, interviews and speeches (Abingdon: Routledge, 2013).

12. Solomon,G.E.A., Carley,S. \& Porter,A.L. How multidisciplinary are the multidisciplinary journals Science and Nature? PloS One 11.4: e0152637 (2016).

13. Callaway,E. Centre of attention Nature 499, 142-143 (2013).

14. Weiss, R. Nip misinformation in the bud Science 358, 427 (2017).

15. Biagioli,M. Peer review pp.624-625 in: The Oxford Companion to the History of Modern Science Heilbron,J.L. (ed.), (Oxford: Oxford University Press, 2003).

16. Scott,A. Peer review and the relevance of science Futures 39, 827-845 (2007).

17. Ciszar,A. The catalogue that made metrics and changed science Nature 551, 163-165 (2017).

18. Kohler,R.E. Landscapes and Labscapes: Exploring the Lab-Field Border in Biology (Chicago: University of Chicago Press, 2012).

19. Livingstone,D.N. Putting Science in its Place: Geographies of Scientific Knowledge (Chicago: University of Chicago Press, 2010).

20. Schaffer,S. Ceremonies of measurement: rethinking the world history of science Annales (English edn.), 70(2), 335-360 (2015).

21. Baldwin,M. Making 'Nature': The History of a Scientific Journal (Chicago: University of Chicago Press, 2015).

22. Jasanoff,S. (ed.) States of Knowledge: The Co-production of Science and the Social Order (Abindgon: Routledge, 2004).

23. Waaijer,C.J., van Bochove,C.A., \& van Eck,N.J. On the map: Nature and Science editorials Scientometrics 86(1), 99-112 (2011).

24. Pickering,A. The Mangle of Practice: Time, Agency, and Science (Chicago: University of Chicago Press, 1995). 
25. Callon,M. What Does it Mean to Say that Economics is Performative? (Centre de Sociologie de I'Innovation Working Paper Series, No.5, Paris, 2016, accessed 20 December 2017); https://halshs.archives-ouvertes.fr/halshs-00091596/document

26. Campbell,P. Statues: an editorial response Nature 549, 334 (2017).

27. Waaijer,C.J., van Bochove,C.A., van Eck,N.J. Journal editorials give indication of driving science issues Nature 463, 157 (2010).

28. Hoey,J. \& Todkill,A.M. An editorial on editorials Canadian Medical Association Journal 167(9), 1006-1007 (2002).

29. Smart,A., Tutton,R., Martin,P., Ellison,G.T. \& Ashcroft,R. The standardization of race and ethnicity in biomedical science editorials and UK biobanks Social Studies of Science 38(3), 407-423 (2008).

30. Waaijer,C.J. Careers in science: Policy issues according to Nature and Science editorials Scientometrics 96(2), 485-495 (2013).

31. BPA Worldwide www.bpaww.com [accessed March 2018]

32. Campbell,P. John Maddox, 1925-2009: in memory of a transformative editor of Nature Nature 458, 807 (2009).

33. Singer,F.S. Will the world come to a horrible end? Science 170, 125 (1970).

34. Anon. The great greenhouse scare Nature 229, 514 (1971).

35. Jaspal,R. \& Nerlich,B. When climate science became climate politics: British media representations of climate change in 1988 Public Understanding of Science 23(2), 122-141 (2014).

36. Hilgartner,S. \& Bosk,C.L.. The rise and fall of social problems: a public arenas model American Journal of Sociology 94(1), 53-78 (1988).

37. Lederman,L.M. \& Malcolm,S.M. The next campaign Science 323, 1265 (2009).

38. Schlesinger,W.H. Carbon trading Science 314, 1217 (2006).

39. Stern Review. The Economics of Climate Change: the Stern Review (Cambridge: Cambridge University Press, 2007).

40. Anon. Future-proofing Nature 528, 164 (2015).

41. Anon. Better climate data required Nature 410, 287 (2001).

42. Anon. The heat is on Nature 438, 296 (2005).

43. McNutt,M. The beyond-two-degree inferno Science 349, 7 (2015).

44. McNutt,M. Ignorance is not an option Science 347, 1293 (2015).

45. Gupta,J. \& Grubb,M. (eds.) Climate Change and European Leadership Amsterdam: Elsevier, 2000). 
46. Shapin,S. Placing the view from nowhere: historical and sociological problems in the location of science Transactions of the Institute of British Geographers 23, 5-12 (1998).

47. Nerlich,B., Forsyth,R., \& Clarke,D. Climate in the news: How differences in media discourse between the US and UK reflect national priorities Environmental Communication: A Journal of Nature and Culture 6(1), 44-63 (2012).

46. Hoppe,R. Lost in translation: boundary work in making climate change governable pp.109-130 in: From climate change to social change: perspectives on science-policy interactions (eds.) Driessen,P., Leroy,P. \& van Vierssen,W. (eds.) (Utrecht: International Books, 2010).

49. Hollin,G.J.S. \& Pearce,W. Tension between scientific certainty and meaning complicates communication of IPCC reports Nature Climate Change 5(8), 753-756 (2015).

50. Turnhout,E., Hisschemöller,M. \& Eijsackers,H. Ecological indicators: between the two fires of science and policy Ecological Indicators 7, 215-228 (2007).

51. Mahony,M. \& Hulme,M. Modelling and the nation: institutionalizing climate prediction in the UK, 1988-92 Minerva 54, 445-470 (2016). 


\section{Methods}

Establishing the Preliminary Corpus. One of the co-authors followed a strict protocol in which they went through every single issue of both journals from 1966 to 2016 and, using a generous criteria of relevance, opened all editorials which could conceivably be related to climate change. Once in the document, they performed an initial keyword search to identify one or more of the following words: 'climate', 'greenhouse', 'carbon', 'warming', 'weather', 'atmosphere', 'pollution'. (Keyword searches for Nature editorials prior to 1998 were not possible since the digital copies of these editorials were scans of the print versions; these editorials were read in their entirety). If one of these keywords was present the editorial was then read carefully to make a determination as to whether it could potentially be relevant for the study. Editorials were then saved in either a 'certain' or a 'maybe' folder. A triangulation was then performed against a 'corpus of opportunity' which the lead author had maintained in real-time since 2003 (and back-dated to 1966) using a more subjective judgement of climate change relevance. This triangulation between two independent methods yielded a preliminary corpus with $n=428$ for Nature and $n=180$ for Science, accounting for between 6 and $7 \%$ of all editorials published by either journal. A further check on the corpus identification was enabled through comparison with Waaijer et al. ${ }^{21}$ (see below).

Identifying Frames and Attributes. We adopted frame theory and analysis ${ }^{49}$ in order to scrutinise systematically the ways in which Nature's and Science's editorials described and communicated climate change to their readerships. Frame analysis is a discourse analysis method, suitable for dissecting how an issue is defined and problematized. 'Frames' are interpretative storylines, created by authors and communicators, that help identify what is at stake in an issue; a frame reveals what an author feels is important about an issue. For this reason framing is never 'ideologically neutral'. Frame analysis therefore offers a rich way to explore how different actors (in our case, editorial authors) define an issue in strategic ways, offering common points of reference and meaning between author and reader ${ }^{50}$. Frames strongly hint at an assumed 'problem-solution formation' ${ }^{49}$. For instance, if climate change is presented principally as a technology/energy challenge, addressing climate change then becomes primarily a matter of mitigating emissions through energy 
systems transitions and innovation, rather than through attending to considerations about, for example, justice, governance, adaptation or resilience.

For the purpose of this research we constructed eight 'issue-specific' frames (i.e., specific to the issue of climate change as engaged by Nature and Science) through a mixed inductivedeductive approach ${ }^{50,51}$. Before the coding commenced we formulated, deductively, eight candidate frames (and their definitions) drawing upon four frame criteria ${ }^{52}$ : identifiable conceptual and linguistic features; commonly observed; easily distinguished from other frames; recognisable by others. The frames and definitions were then refined, iteratively, during the two pilot phases (see below) as we inductively sought to apply the above four criteria. Working collaboratively together through small samples of the corpus helped the four authors identify areas where frames either overlapped or where they lacked clarity of definition.

This led us to make various changes to our initial (deductive) frame-set. First, we conceived of our frames as 'challenges' to better reflect the 'problem-solution formation' evident in many of the editorials. Second, we distinguished between 'challenges' and what we called 'attributes': i.e., 'global', 'urgent', 'policy' (see Table 1). These were attributes of the challenge rather than a distinct frame of their own and their presence or not in an editorial was identified using a binary classification. Third, following from the above considerations, we adjusted our frame-set by re-classifying one frame ('policy challenge') as an attribute and adding a new eighth challenge ('moral/ethical'). Finally, we decided to distinguish between the one 'primary' (i.e., dominant) frame (challenge) of an editorial and any number of 'other frames'.

Pilot Coding. For the purpose of testing and refining the frame-set and the coding framework two pilot exercises were conducted. For each pilot, 15 editorials were extracted at random from each journal giving a pilot set of 30 editorials. All four authors then coded independently using a simple binary system (0 or 1 ) for presence/absence of each frame and attribute. After the first pilot, the authors deliberated collectively on how to modify the frame-set and frame captions (see above). The re-adjusted (and final) coding scheme was then re-tested in the second pilot. Following this second pilot the authors resolved any remaining ambiguities in the frame captions and agreed on how to proceed with coding the 
whole corpus (see below). Fleiss kappa scores (kappa scores adjusted for use with multiple coders rather than just $\mathrm{two}^{53}$ ), were used to measure inter-coder reliability between the four coders (authors) in each of the two pilots (see Supplementary Table 5). Reliability scores increased between the two pilots, although remained only moderate-to-fair. For this reason each author used an agreed colour code to flag editorials in the full corpus which they deemed particularly difficult to code and these were resolved through group deliberation (see below). Coding 'attributes' was considerably more reliable than coding 'challenges' and kappa scores here revealed substantial agreement.

Coding the Corpus. For the coding of the full preliminary corpus, each of the 608 editorials was randomly allocated to one of the four authors. Each author had common instructions to highlight in red the editorials they judged should definitely be removed from the corpus, in orange the editorials that might be considered 'out of scope' and where a collective determination should be made, and in blue the editorials which were particularly difficult to code. In determining between the primary and 'other' frames of an editorial, authors interpreted the editorials in their historical context. In cases where an editorial referred to specific external documents or reports - which themselves framed climate change in particular ways - the authors coded the frames used by the author of the editorial, not the frames of the external source. Similarly, for editorials where climate change was mentioned as a substantive example of a wider issue the authors judged the frame in which climate change was placed, not the framing of the wider issue (which on occasions could be at odds with each other). Finally, in coding 'other frames', the authors erred on the side of inclusion rather than exclusion (i.e., if in doubt about the relevance of an 'other frame' the coders would include it).

Confirming the Final Corpus. The authors resolved through collective deliberation the coding decisions for all editorials which had been flagged red, orange or blue. Where the authors could not come to a consensus regarding the inclusion of particular editorials in the final corpus (less than 10 instances) the lead author made a final decision. The orange editorials that were included in the final corpus (28 for Nature; 11 for Science) were all coded collaboratively. All four authors also discussed and coded collaboratively each blue flag in the preliminary corpus (i.e., where frame identification was judged particularly difficult). This sub-set consisted of 29 editorials in Nature and 17 in Science. Combining 
these two sub-sets meant that 85 of the more challenging editorials to code (57 in Nature and 28 in Science; around 17\% of the final corpus) were coded collaboratively, thus assuaging to some degree the relatively modest kappa scores secured in the second pilot. The series of iterative processes described above were designed to reach consistent decisions regarding inclusion/exclusion of editorials in the final corpus and consistent judgements about frame codes.

The final corpus carried forward for analysis comprised 333 editorials for Nature (a loss of $30 \%$ of editorials compared to the preliminary corpus) and 160 editorials for Science (9\% loss). The final corpus for the decade 2000-2009 was compared with that extracted by Waaijer et al. ${ }^{21}$ These authors extracted all Nature and Science editorials and through an automated word search and subsequent cluster analysis identified those that were deemed to be concerned with 'climate change' (NB. Their study was not concerned with climate change per se). For this decade Waaijer identified 80 such editorials in Nature and 65 in Science. This compared with 136 Nature editorials in the final corpus used in this study (70\% more than Waaijer) and 74 for Science (15\% more). These differences reflect different methodologies-automated versus interpretative-and to the fact that the current authors read carefully each candidate editorial before reaching a decision. This study also retained editorials in which climate change was a substantive example of a wider issue or concern, whereas Waaijer's analysis was designed to allocate all editorials to just one of 15 exclusionary editorial clusters.

Data Availability. All the editorials analysed in this study are available through Nature and Science web-site archives. The details (date, title, volume, DOI) of the final corpus of 493 editorials designed 'climate change' are available at the public data repository FigShare, https://doi.org/10.6084/m9.figshare.5878303.v1.

\section{Additional References}

49. Entman,R,B. Framing: toward clarification of a fractured paradigm Journal of Communication 43, 51-58 (1993).

50. Nisbet,M.C. Communicating climate change: why frames matter for public engagement Environment 51(2), 12-23 (2009).

51. de Vreese, C.H. Framing Europe: Television News and European Integration

(Amsterdam: Aksant Academic Publishers, 2002). 
52. Cappella, J.N. \& Jamieson, K.H. Spirit of Cynicism: the Press and the Public Good (New York: Oxford University Press, 1997).

53. Fleiss, J.L. Measuring nominal scale agreement among many raters Psychological Bulletin 76, 378-382 (1971). 


\section{Framing the Challenge of Climate Change in Nature and Science Editorials}

Mike Hulme, Noam Obermeister, Samuel Randalls and Maud Borie

\section{Supplementary Information}

Supplementary Note 1: Analysis of citations and altmetric scores. To gain a sense of the relative salience of climate change editorials in these two journals we analysed all editorials in our corpus for 2015 and 2016, a total of 38 editorials. In order to evaluate both academic and non-academic salience we used altmetrics, which gives an idea of how frequently editorials were shared beyond academic spheres, e.g. shared on Twitter, Pinterest, Reddit, Facebook, etc., and also Scopus, which identifies the number of citations in formal academic literature. Results are in Supplementary Table 1.

Editorials in both Nature and Science gain broadly similar on-line attention with average altmetrics scores greater than 100 . This suggest that editorials in both journals are frequently shared and hence contribute to wider academic and public discussions. With regard to citations however, editorials in Science are cited significantly more frequently than editorials in Nature (on average by a factor of 9). This seems very likely due to the association of named authors with Science editorials. It is much easier to locate them in search engines and also easier for academic authors to situate attributed editorials in particular debates. In contrast, locating anonymous Nature editorials in Scopus is much more challenging and citing an anonymous commentary in specific debates less appealing.

Supplementary Table 1: Citations (from Scopus) and altmetrics scores for Nature and Science 'climate change editorials' published in 2015 and 2016. [Census date: 22 November 2017]. The former captures formal scientific visibility, the latter the broader informal salience of the editorials.

\begin{tabular}{|l|c|c|c|c|c|}
\hline & $\begin{array}{c}\text { Number of } \\
\text { editorials }\end{array}$ & Total cites & $\begin{array}{c}\text { Average } \\
\text { cites }\end{array}$ & Total Altmetric score & $\begin{array}{c}\text { Average } \\
\text { score }\end{array}$ \\
\hline Nature & 26 & 13 & 0.5 & 3414 & 131 \\
\hline Science & 12 & 55 & 4.6 & 1231 & 103 \\
\hline
\end{tabular}


Supplementary Note 2: Analysis of Science editorials' authors. Since all Science editorials are attributed to named individuals we extracted information about the authors of all 160 'climate change editorials' in our corpus (Supplementary Table 2). The number of editorials published under the editorship of each editor-in-chief (EIC), as well as how many they personally authored, is shown in Supplementary Table 3. EICs did not only author editorials during their tenure. For example, Phil Abelson authored editorials until the year 2000, even though he ceased being EIC in 1984. The significance of different EICs for the framing of the climate change challenge is clear (Supplementary Table 3). For Abelson and Koshland, climate change was a 'scientific challenge' ( $\mathrm{SCl}$ ) in, respectively, $59 \%$ and $45 \%$ of editorials they commissioned and/or authored during their tenure. With Kennedy as EIC, however, it was only $13 \%$, whereas $22 \%$ of his commissioned editorials framed climate change primarily as a 'communication challenge' (COM).

Supplementary Table 2: Author details of all 'climate change editorials' in our corpus published in Science $(n=160)$.

\begin{tabular}{|c|c|c|c|c|c|c|}
\hline Year & EIC & Name & Country & Location & Role & Gender \\
\hline 2016 & \multirow{3}{*}{$\begin{array}{l}\text { Jeremy } \\
\text { Berg }\end{array}$} & Sir David King & UK & & \begin{tabular}{|l|} 
UK Foreign Secretary's Special \\
Representative for Climate Change
\end{tabular} & M \\
\hline 2016 & & Patricia Espinosa & Germany & & Executive Secretary of UNFCCC & $\mathrm{F}$ \\
\hline 2016 & & Johan Rockström & Sweden & Stockholm & Academic/Chair of the Earth League & M \\
\hline 2015 & \multirow{16}{*}{ Marcia } & Marcia McNutt & US & DC & Editor in Chief & $\mathrm{F}$ \\
\hline 2015 & & Alan I. Leshner & US & DC & $\begin{array}{l}\text { Chief Executive Officer or AAAS and } \\
\text { Publisher of Science }\end{array}$ & M \\
\hline 2015 & & Marcia McNutt & US & DC & Editor in Chief & $\mathrm{F}$ \\
\hline 2015 & & Marcia McNutt & US & DC & Editor in Chief & $\mathrm{F}$ \\
\hline 2015 & & Marcia McNutt & US & DC & Editor in Chief & $\mathrm{F}$ \\
\hline 2015 & & Marcia McNutt & US & DC & Editor in Chief & $\mathrm{F}$ \\
\hline 2015 & & Diana H. Wall & US & Colorado & Academic/Science, Soils Institute & $F$ \\
\hline 2015 & & Fran Ulmer & US & & Chair of US Arctic Research Commission & $\mathrm{F}$ \\
\hline 2015 & & Hoesung Lee & Switzerland & & $\begin{array}{l}\text { Chair of the Intergovernmental Panel on } \\
\text { Climate Change }\end{array}$ & M \\
\hline 2014 & & Marcia McNutt & US & DC & Editor in Chief & $F$ \\
\hline 2014 & & Marcia McNutt & US & DC & Editor in Chief & $\mathrm{F}$ \\
\hline 2014 & & David Titley & US & & Academic /Retired Admiral & M \\
\hline 2014 & & Kirk R. Smith & US & California & Professor/Global environmental health & M \\
\hline 2014 & & Sally M. Benson & US & Stanford & $\begin{array}{l}\text { Director of the Precourt Institute for Energy } \\
\text { and the Global Climate and Energy } \\
\text { Project/Academic }\end{array}$ & $\mathrm{F}$ \\
\hline 2013 & & Marcia McNutt & US & DC & Editor in Chief & $\mathrm{F}$ \\
\hline 2013 & & Marcia McNutt & US & DC & Editor in Chief & $\mathrm{F}$ \\
\hline
\end{tabular}




\begin{tabular}{|c|c|c|c|c|c|c|}
\hline 2013 & & Martin Rees & UK & Cambridge & Member of House of Lords/Astronomer royal & M \\
\hline 2013 & & \begin{tabular}{|l|} 
Bassam Z. \\
Shakhashiri \\
\end{tabular} & US & Wisconsin & Professor/Chemistry & M \\
\hline 2013 & & $\begin{array}{l}\text { Susan. Haig, } \\
\text { Thomas Martin, } \\
\text { Charles van Riper, } \\
\text { T. Douglas Beard } \\
\text { Jr. }\end{array}$ & US & & Ecologists & $\begin{array}{l}\mathrm{F} \mathrm{M} \mathrm{M} \\
\mathrm{M}\end{array}$ \\
\hline 2012 & & Alan I. Leshner & US & DC & $\begin{array}{l}\text { Chief executive officer of AAAS/Publisher of } \\
\text { Science }\end{array}$ & $M$ \\
\hline 2012 & & \begin{tabular}{|l|} 
Máire \\
Geoghegan-Quinn
\end{tabular} & EU & & $\begin{array}{l}\text { European Commissioner for Research, } \\
\text { Innovation and Science }\end{array}$ & $\mathrm{F}$ \\
\hline 2011 & & \begin{tabular}{|l|} 
William L. \\
Chameides
\end{tabular} & US & Durham & $\begin{array}{l}\text { Dean of the Nicholas School of the } \\
\text { Environment }\end{array}$ & M \\
\hline 2010 & & Donald Kennedy & US & DC & Editor Emeritus of Science & $M$ \\
\hline 2010 & & Bruce Alberts & US & DC & Editor in chief of Science & M \\
\hline 2010 & & Bruce Alberts & US & DC & Editor in chief of Science & M \\
\hline 2010 & & Brooks Hanson & US & DC & $\begin{array}{l}\text { Deputy Editor for Physical Sciences in } \\
\text { Science }\end{array}$ & M \\
\hline 2010 & & Ralph Cicerone & US & & President of US Academy of Science & $M$ \\
\hline 2010 & & Anette Schaven & Germany & & $\begin{array}{l}\text { Minister of the Federal Ministry of Education } \\
\text { and Research }\end{array}$ & $\mathrm{F}$ \\
\hline 2010 & & John Church & Australia & & CSIRO (Research Centre) & $M$ \\
\hline 2010 & & $\begin{array}{l}\text { William H. } \\
\text { Schlesinger } \\
\end{array}$ & US & Milibrook & $\begin{array}{l}\text { President of the Cary Institute of Ecosystem } \\
\text { Studies }\end{array}$ & M \\
\hline 2009 & & Eric J. Barron & US & Colorado & Director of the NCAR & M \\
\hline 2009 & & Steven Chu & US & & $\begin{array}{l}\text { US. Secretary of Energy/Nobel Laureate in } \\
\text { physics. }\end{array}$ & M \\
\hline 2009 & & $\begin{array}{l}\text { Rosina M. } \\
\text { Bierbaum and } \\
\text { Robert B. Zoellick } \\
\end{array}$ & US & & $\begin{array}{l}\text { Academic (University of Michigan)/ Co- } \\
\text { Director of the World Development Report; } \\
\text { President of World Development Bank }\end{array}$ & FM \\
\hline 2009 & $\begin{array}{l}\text { Bruce } \\
\text { Albert }\end{array}$ & \begin{tabular}{|l} 
Walter V. Reid, \\
Catherine \\
Bréchignac, Yuan \\
Tseh Lee
\end{tabular} & $\begin{array}{l}\text { US, France, } \\
\text { Taipei }\end{array}$ & & ICSU & M F M \\
\hline 2009 & & $\begin{array}{l}\text { Paul Falkowski } \\
\text { and Robert } \\
\text { Goodman } \\
\end{array}$ & US & Rutgers & Rutgers Energy Institute & M \\
\hline 2009 & & M. S. Swaminatha & India & Chennai & UNESCO Chair of ecotechnology & $M$ \\
\hline 2009 & & Albert Grimaldi & Monaco & Monaco & Prince of Monaco & $M$ \\
\hline 2009 & & Glenn Schweitzer & US & DC & $\begin{array}{l}\text { Director of Eurasian Programs at the } \\
\text { U.S.National Academy }\end{array}$ & $M$ \\
\hline 2009 & & Sir David King & UK & Oxford & $\begin{array}{l}\text { Director of the Smith School of Enterprise } \\
\text { and the Environment, }\end{array}$ & M \\
\hline 2009 & & $\begin{array}{l}\text { Leon M. } \\
\text { Lederman and } \\
\text { Shirley M. } \\
\text { Malcom } \\
\end{array}$ & US & & Academic/AAAS & M F \\
\hline 2008 & & $\begin{array}{l}\text { Jim Wells and } \\
\text { Mary Woolley }\end{array}$ & US & $\begin{array}{l}\text { Alexandria } \\
\text { and San } \\
\text { Francisco } \\
\end{array}$ & $\begin{array}{l}\text { Mary Woolley is president and chief } \\
\text { executive officer of Research America. Jim } \\
\text { Wells is an academic }\end{array}$ & M F \\
\hline 2008 & & Raman Sukumar & India & Bangalore & $\begin{array}{l}\text { Professor of ecology at the Indian Institute of } \\
\text { Science }\end{array}$ & $M$ \\
\hline 2008 & & \begin{tabular}{|l|} 
James Tiedje and \\
Timothy Donohue
\end{tabular} & US & & Professors of microbiology and bacteriology & M M \\
\hline 2008 & & $\begin{array}{l}\text { Susan Solomon } \\
\text { and Martin } \\
\text { Manning }\end{array}$ & US & & $\begin{array}{l}\text { Co-chair of IPCC WG } 1 \text { and former chair of } \\
\text { IPCC WG } 1\end{array}$ & FM \\
\hline
\end{tabular}




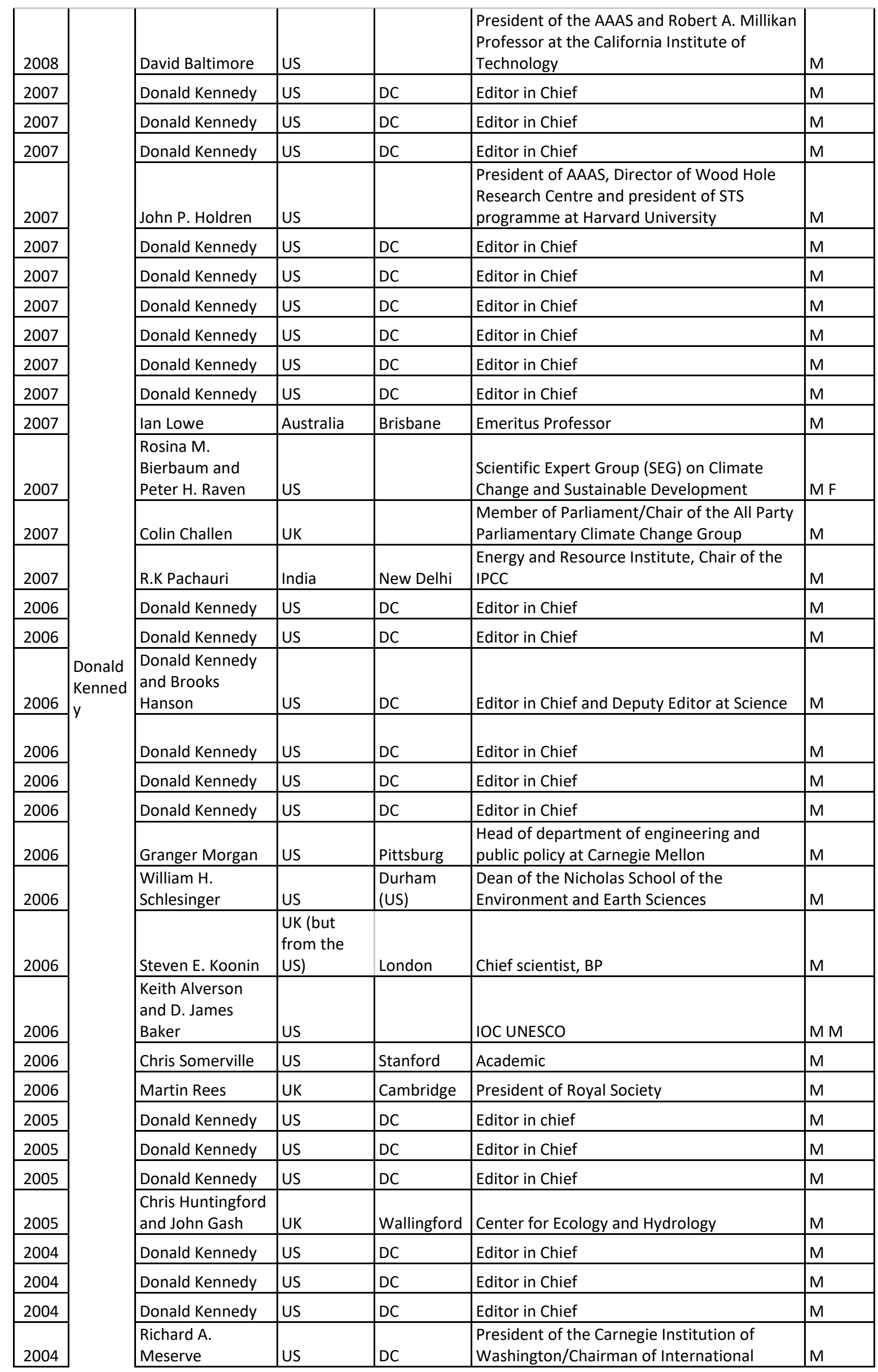




\begin{tabular}{|c|c|c|c|c|c|c|}
\hline & & & & & $\begin{array}{l}\text { Nuclear Safety Group of the International } \\
\text { Atomic Energy Agency }\end{array}$ & \\
\hline 2004 & & David Baltimore & US & California & $\begin{array}{l}\text { President of the California Institute of } \\
\text { Technology in Pasadena }\end{array}$ & $M$ \\
\hline 2004 & & Jeffrey D. Sachs & US & New York & $\begin{array}{l}\text { Director of the Earth Institute at Columbia } \\
\text { University and Special Advisor to United } \\
\text { Nations Secretary-General Kofi Annan on the } \\
\text { Millennium Development Goals }\end{array}$ & $M$ \\
\hline 2004 & & Mary R. Albert & US & & $\begin{array}{l}\text { Chair of the U.S. Planning Committee for IPY } \\
\text { 2007-2008 }\end{array}$ & $\mathrm{F}$ \\
\hline 2004 & & $\begin{array}{l}\text { Robert B. } \\
\text { Gagosian }\end{array}$ & US & & $\begin{array}{l}\text { President and director of the Woods Hole } \\
\text { Oceanographic Institution in Woods Hole, } \\
\text { Massachusetts, and a member of the U.S. } \\
\text { Commission on Ocean Policy Science } \\
\text { Advisory Panel }\end{array}$ & $M$ \\
\hline 2003 & & Donald Kennedy & US & DC & Editor in Chief & $M$ \\
\hline 2003 & & Donald Kennedy & US & DC & Editor in Chief & $M$ \\
\hline 2003 & & Donald Kennedy & US & DC & Editor in Chief & $M$ \\
\hline 2003 & & Donald Kennedy & US & DC & Editor in Chief & $M$ \\
\hline 2002 & & Donald Kennedy & US & DC & Editor in Chief & $M$ \\
\hline 2002 & & Donald Kennedy & US & DC & Editor in Chief & $M$ \\
\hline 2002 & & Donald Kennedy & US & DC & Editor in Chief & M \\
\hline 2002 & & Crispin Tickell & US & DC/Boston & $\begin{array}{l}\text { Senior visiting fellow at the Harvard } \\
\text { University Center for the Environment and } \\
\text { chairman of the Climate Institute }\end{array}$ & M \\
\hline 2002 & & Kirk R. Smith & US & California & Professor of environmental health sciences & $M$ \\
\hline 2002 & & Tony McMichael & Australia & Canberra & $\begin{array}{l}\text { Director of National centre for epidemiology } \\
\text { and population health, }\end{array}$ & M \\
\hline 2001 & & Saleemul Huq & $\begin{array}{l}\text { UK and } \\
\text { Bangladesh }\end{array}$ & & $\begin{array}{l}\text { Chairman of the Bangladesh Centre for } \\
\text { Advanced Studies in Dhaka, Bangladesh, and } \\
\text { director of the Climate Change Programme } \\
\text { of the International Institute for } \\
\text { Environment and Development in London }\end{array}$ & $M$ \\
\hline 2001 & & Jonathan Lash & US & DC & $\begin{array}{l}\text { President of the World Resources Institute in } \\
\text { Washington }\end{array}$ & M \\
\hline 2001 & & Joint Statement & & & $\begin{array}{l}\text { Joint statement by different academies of } \\
\text { science }\end{array}$ & n.a. \\
\hline 2001 & & Donald Kennedy & US & DC & Editor in Chief & $M$ \\
\hline 2001 & & John Lawton & UK & & $\begin{array}{l}\text { Academic/Chief executive of the UK Natural } \\
\text { Environment Research Council. }\end{array}$ & M \\
\hline 2001 & & Donald Kennedy & US & DC & Editor in Chief & M \\
\hline 2000 & & Norman Myers & UK & & British environmentalist & M \\
\hline 2000 & & Philip Abelson & US & DC & Deputy Editor of Science & $M$ \\
\hline 2000 & & Philip Abelson & US & DC & Deputy Editor of Science & $M$ \\
\hline 2000 & & Philip Abelson & US & DC & Deputy Editor of Science & $M$ \\
\hline 2000 & & Donald Kennedy & US & DC & Editor in Chief & $M$ \\
\hline 1999 & \multirow{5}{*}{$\begin{array}{l}\text { Floyd } \\
\text { Bloom }\end{array}$} & Rush Holt & US & & $\begin{array}{l}\text { U.S. Congressman from central New } \\
\text { Jersey/Physicist }\end{array}$ & $M$ \\
\hline 1997 & & $\begin{array}{l}\text { Gro Harlem } \\
\text { Brundtland }\end{array}$ & Norway & & Norwegian politician & $\mathrm{F}$ \\
\hline 1997 & & Robert M. May & $\begin{array}{l}\text { UK/Australi } \\
\text { a }\end{array}$ & & $\begin{array}{l}\text { Chief scientific adviser to HM Government } \\
\text { and Office of Science and Technology } \\
\text { committee }\end{array}$ & $M$ \\
\hline 1997 & & Philip Abelson & US & DC & Deputy Editor of Science & $M$ \\
\hline 1996 & & $\begin{array}{l}\text { Vice President Al } \\
\text { Gore }\end{array}$ & US & DC & $\begin{array}{l}\text { Vice President. Editorial text adapted from a } \\
\text { speech for AAAS annual meeting }\end{array}$ & $M$ \\
\hline
\end{tabular}




\begin{tabular}{|c|c|c|c|c|c|c|}
\hline 1995 & & George A. Olah & US & California & $\begin{array}{l}\text { Academic/ Nobel Prize for work on } \\
\text { carbocations }\end{array}$ & M \\
\hline 1995 & & Philip Abelson & US & DC & Deputy Editor of Science & M \\
\hline 1993 & \multirow{29}{*}{$\begin{array}{l}\text { Daniel } \\
\text { Koshlan } \\
\text { d }\end{array}$} & Brooks Hanson & US & DC & Senior Editor of Science & M \\
\hline 1993 & & Daniel Koshland & US & DC & Editor in Chief & $M$ \\
\hline 1992 & & \begin{tabular}{|l|} 
F. Sherwood \\
Rowland \\
\end{tabular} & US & California & Professor of chemistry, President of AAAS & M \\
\hline 1992 & & Philip Abelson & US & DC & Deputy Editor of Science & M \\
\hline 1992 & & Philip Abelson & US & DC & Deputy Editor of Science & $M$ \\
\hline 1992 & & $\begin{array}{l}\text { Brooks Hanson } \\
\text { and David Voss } \\
\end{array}$ & US & DC & Both senior editors at Science & M M \\
\hline 1992 & & Philip Abelson & US & DC & Deputy Editor of Science & M \\
\hline 1992 & & Philip Abelson & US & DC & Deputy Editor of Science & $M$ \\
\hline 1991 & & Philip Abelson & US & DC & Deputy Editor of Science & $M$ \\
\hline 1991 & & Philip Abelson & US & DC & Deputy Editor of Science & $M$ \\
\hline 1990 & & Philip Abelson & US & DC & Deputy Editor of Science & $M$ \\
\hline 1990 & & Philip Abelson & US & DC & Deputy Editor of Science & $M$ \\
\hline 1990 & & Philip Abelson & US & DC & Deputy Editor of Science & M \\
\hline 1990 & & R. Brooks Hanson & US & DC & Senior Editor of Science & $M$ \\
\hline 1990 & & Philip Abelson & US & DC & Deputy Editor of Science & $M$ \\
\hline 1989 & & Daniel Koshland & US & DC & Editor & $M$ \\
\hline 1989 & & Philip Abelson & US & DC & Publisher & $M$ \\
\hline 1989 & & Philip Abelson & US & DC & Publisher & M \\
\hline 1989 & & John I. Brauman & US & DC & Deputy Editor of Science & M \\
\hline 1989 & & Philip Abelson & US & DC & Publisher & $M$ \\
\hline 1989 & & Daniel Koshland & US & DC & Editor & M \\
\hline 1989 & & Philip Abelson & US & DC & Deputy Editor of Science & M \\
\hline 1989 & & Philip Abelson & US & DC & Publisher & M \\
\hline 1988 & & Daniel Koshland & US & DC & Editor & M \\
\hline 1988 & & Daniel Koshland & US & DC & Editor & M \\
\hline 1988 & & Phil Abelson & US & DC & Deputy editor & M \\
\hline 1986 & & Phil Abelson & US & DC & Deputy editor & M \\
\hline 1986 & & Phil Abelson & US & DC & Deputy editor & $M$ \\
\hline 1985 & & Roger Revelle & US & California & $\begin{array}{l}\text { Professor of science and public policy, } \\
\text { University of California }\end{array}$ & $M$ \\
\hline 1983 & & Phil Abelson & US & DC & Editor & M \\
\hline 1982 & & Gilbert F. White & US & Colorado & Academic, behavioural sciences & M \\
\hline 1979 & & Phil Abelson & US & DC & Editor & M \\
\hline 1979 & & William D. Carey & US & DC & $\begin{array}{l}\text { Executive Officer of the AAAS from } 1975 \\
\text { through } 1987\end{array}$ & $M$ \\
\hline 1978 & & Robert G. Fleagle & US & DC & $\begin{array}{l}\text { Department of Atmospheric Science, } \\
\text { University of Washington }\end{array}$ & M \\
\hline 1978 & & Edward E. David & US & DC & $\begin{array}{l}\text { President elect AAAS and President EXXON } \\
\text { research and engineering }\end{array}$ & $M$ \\
\hline 1977 & & Charles J. Hitch & US & DC & Resources for the future & M \\
\hline 1977 & & Phil Abelson & US & DC & Editor & $M$ \\
\hline 1976 & & Phil Abelson & US & DC & Editor & M \\
\hline 1976 & & Phil Abelson & US & DC & Editor & M \\
\hline 1975 & $\begin{array}{l}\text { Phil } \\
\text { Abelson }\end{array}$ & William D. Carey & US & DC & $\begin{array}{l}\text { Executive Officer of AAAS and publisher of } \\
\text { Science from } 1975 \text { through } 1987\end{array}$ & $M$ \\
\hline
\end{tabular}




\begin{tabular}{|c|c|c|c|c|c|}
\hline 1974 & Alvin Weirnberg & US & DC & Federal Energy Agency & M \\
\hline 1972 & Phil Abelson & US & DC & Editor & $M$ \\
\hline 1970 & Fred Singer & US & DC & $\begin{array}{l}\text { Chairman, Committee on Environmental } \\
\text { Quality, AGU }\end{array}$ & M \\
\hline 1967 & Phil Abelson & US & DC & Editor & $M$ \\
\hline 1966 & Walter Orr Robert & US & Colorado & Director, NCAR & $M$ \\
\hline 1966 & Phil Abelson & US & DC & Editor & $M$ \\
\hline
\end{tabular}

In their personally authored editorials the distinction is even clearer. Of Abelson's 31 authored editorials between 1966 and 2000, 87\% framed climate change primarily as either a technology/energy challenge $(\mathrm{TECH} ; \mathrm{n}=16)$ or a scientific challenge $(\mathrm{SCl} ; \mathrm{n}=11)$. In contrast, of Kennedy's 31 authored editorials between 2000 and 2010, 39\% were a communication challenge (COM; $n=12$ ) and $23 \%$ each as a technology/energy challenge (TECH) and an institutional/governance challenge (GOV). These editors' disciplinary backgrounds and personal commitments are likely significant here: Abelson, a physicist with a strong background in nuclear energy and a personal interest in global energy challenges;

Kennedy, a biologist but with strong interests in public policy and global climate change.

Supplementary Table 3: Number of 'climate change editorials' in Science published under each editor-in-chief, together with the number of editorials they each personally authored. Note: some editorials were authored by EICs after their tenure as editor. The predominant 'challenges' framed by the editorials under each EIC's tenure is also indicated (refer back to

Table 2 in main text for codes).

\begin{tabular}{|c|c|c|c|c|c|c|}
\hline Editor & Dates & $\begin{array}{c}\text { Total } \\
\text { commissioned }\end{array}$ & $\%$ & $\begin{array}{l}\text { Predominant frames } \\
\text { amongst those } \\
\text { commissioned }\end{array}$ & $\begin{array}{c}\text { Personally } \\
\text { authored }\end{array}$ & $\%$ \\
\hline Phil Abelson & $1966-1984$ & 17 & 11 & $10 x \mathrm{SCl} 5 \times \mathrm{TTECH}$ & 31 & 19 \\
\hline Daniel Koshland & 1984-1995 & 29 & 18 & 13xSCI 10xTECH & 5 & \\
\hline Flood Bloom & $1995-2000$ & 7 & 4 & $3 \times T E C H ~ 2 x D E V$ & 0 & \\
\hline Donald Kennedy & $2000-2008$ & 60 & 38 & $\begin{array}{c}\text { 16xTECH 13xCOM } \\
12 \times G O V 8 x S C l\end{array}$ & 31 & 19 \\
\hline Bruce Albert & $2008-2013$ & 25 & 16 & $8 \times S C I 7 x C O M$ 4xTECH & 2 & \\
\hline Marcia McNutt & $2013-2015$ & 19 & 12 & 5xTECH 4xCOM 3xGOV & 9 & \\
\hline Jeremy Berg & $2015-2016$ & 3 & 2 & & 0 & \\
\hline
\end{tabular}


Supplementary Table 2 allows further analysis of the author profiles of Science's editorials. Some 91 editorials (57\%) were authored by Science's EICs, deputy editors, senior editor publishers or others working for the AAAS. This is consistent with Science being the flagship journal of the American Association for the Advancement of Science. $84 \%$ of editorials were authored by individuals located in the USA (Supplementary Table 4) and of these, about two thirds were located in Washington DC. (This is an estimation since some authors have multiple affiliations and may reside in different places). With regards to gender, only 17 (11\%) of all Science editorials were single authored by women (a further eight were coauthored by women), and nine of these were authored by the first female EIC of Science, Marcia McNutt. Before McNutt took over as EIC in 2013, only four out of 138 editorials in Science had been single-authored by a woman.

Supplementary Table 4: Location of authors of Science's climate change editorials

\begin{tabular}{|c|c|c|c|c|}
\hline & USA & Europe & Rest of the World & Total \\
\hline Number & 135 & 17 & 8 & 160 \\
\hline$\%$ & 84 & 11 & 5 & \\
\hline
\end{tabular}

Supplementary Table 5: Inter-coder reliability scores from the two pilot exercises. 'Attributes' were only coded in the second pilot.

\begin{tabular}{|l|c|c|}
\hline Fleiss kappa scores & Nature & Science \\
\hline Pilot 1 'challenges' & 0.17 & 0.35 \\
\hline Pilot 2 'challenges' & 0.32 & 0.39 \\
\hline & & \\
\hline Pilot 2 'attributes' & 0.66 & 0.65 \\
\hline
\end{tabular}

